\title{
Butylated hydroxytoluene protects bull sperm surface protein-P25b in different extenders following cryopreservation
}

\author{
A. M. Khumran ${ }^{1}$ (D, N. Yimer², Y. Rosnina' ${ }^{2}$, H. Wahid², M. O. Ariff ${ }^{3}$, H. Homayoun ${ }^{4}$, K. Asmatullah ${ }^{2}$ and T. K. Bello
}

1. Department of Theriogenology and Production, Faculty of Veterinary Medicine, Ahmadu Bello University, Zaria, Nigeria; 2. Department of Veterinary Clinical Studies, Faculty of Veterinary Medicine, Universiti Putra Malaysia, 43400 UPM Serdang, Selangor, Malaysia; 3. Department of Veterinary Pre-clinical Studies, Faculty of Veterinary Medicine, Universiti Putra Malaysia, 43400 UPM Serdang, Selangor, Malaysia; 4. Department of Veterinary Pathology and Microbiology, Faculty of Veterinary Medicine, Universiti Putra Malaysia, 43400 UPM Serdang, Selangor, Malaysia; 5. Biotechnology Research Programme, National Animal Production Research Institute, Zaria, Nigeria.

Corresponding author: N. Yimer, e-mail: nurhusien@upm.edu.my

Co-authors: AMK: kmarmiyau@abu.edu.ng, YR: rosninanuris@upm.edu.my, HW: wahidh@upm.edu.my, MOA: mo_ariff@upm.edu.my, HH: h.hani1975@gmail.com, KA: asmatullah.kaka@gmail.com, TKB: taiwokamarbello@gmail.com

Received: 06-08-2019, Accepted: 24-02-2020, Published online: 11-04-2020

doi: www.doi.org/10.14202/vetworld.2020.649-654 How to cite this article: Khumran AM, Yimer N, Rosnina Y, Wahid H, Ariff MO, Homayoun H, Asmatullah K, Bello TK (2020) Butylated hydroxytoluene protects bull sperm surface protein-P25b in different extenders following cryopreservation, Veterinary World, 13(4): 649-654.

\begin{abstract}
Aim: The aim of this study was to investigate the effects of different concentration of butylated hydroxytoluene (BHT) on sperm membrane surface protein "P25b" from cryopreserved bull semen in either lecithin based Bioxcell ${ }^{\circledR}$ (BX) or two eggyolk based extenders, tris-egg yolk (TEY), and citrate-egg yolk (CEY).

Materials and Methods: Forty-five semen samples, 15 each were extended with either BX, TEY, or CEY extender which contained different concentrations $(0.0$ - control, $0.5,1.0,1.5,2.0$, and $3.0 \mathrm{mM} / \mathrm{mL})$ of BHT. The extended semen samples were frozen at a concentration of $20 \times 10^{6} / \mathrm{mL}$ in $0.25 \mathrm{~mL}$ straws and stored in liquid nitrogen for 2 weeks. The frozen samples were thereafter thawed, proteins extracted and analyzed for quantities of protein P25b through direct sodium dodecyl sulfate-polyacrylamide gel electrophoresis gel densitometry. Peptides were confirmed by Western blotting (WB).
\end{abstract}

Results: Results showed that supplementation of BHT improved $(\mathrm{p}<0.05)$ quantity of protein P25b at concentrations of $0.5 \mathrm{mM} / \mathrm{mL}$ for BX and at $1.0 \mathrm{mM} / \mathrm{mL}$ for TEY and CE when compared with the controls and other treatments.

Conclusion: BHT supplementation at 0.5 in BX and $1.0 \mathrm{mM} / \mathrm{mL}$ in TEY and CEY has protected bull sperm fertility marker protein P25b in frozen-thawed bull sperm.

Keywords: bull sperm, butylated hydroxytoluene, extender, P25b, Western blotting.

\section{Introduction}

Semen cryopreservation has allowed specific opportunities for the conservation of genetic resources through semen banks, guarantee of a constant commercial supply of semen, and collaboration in breed improvement programs by artificial insemination [1]. It has been agreed on, that sperm fertility is challenged following cryopreservation. This occurs due to biophysical damage on spermatozoa that results from the effects of freezing and thawing procedures. The consequences of these procedures are numerous and multifactorial, involving temperature, osmotic, and oxidative effects. During cryopreservation, sperm damage can occur due to damage to the membrane structure due to lipid peroxidation [2]. Cholesterol to phospholipid ratio of sperm bio-membranes gets disturbed mainly due to cholesterol efflux and the generation

Copyright: Khumran, et al. Open Access. This article is distributed under the terms of the Creative Commons Attribution 4.0 International License (http://creativecommons.org/licenses/ by/4.0/), which permits unrestricted use, distribution, and reproduction in any medium, provided you give appropriate credit to the original author(s) and the source, provide a link to the Creative Commons license, and indicate if changes were made. The Creative Commons Public Domain Dedication waiver (http:// creativecommons.org/publicdomain/zero/1.0/) applies to the data made available in this article, unless otherwise stated. of numerous reactive oxygen species (ROS) [3]. The resultant sperm cryo-injuries also involved subtle damage that partially explained the reduced sperm fertility after thawing, such as the damage to the bull sperm surface protein "P25b." Certain proteins, including $\mathrm{P} 25 \mathrm{~b}$ produced by epithelial cells, are acquired from the lumen of the epididymis by spermatozoa during transit. The intraluminal protein sperm surface interaction anchored the proteins to the sperm membrane and modified the sperm head such that these proteins behaved like an integral part of sperm when submitted to different treatments [4]. This process is essential to generate actively motile and fertile sperm [5], with P25b playing a major role in the regulation of cellular activities that lead to acrosome reaction, recognition, binding, and sperm penetration of zona pellucida of the oocyte during fertilization [6]. Other proteins that are considered homologous to $\mathrm{P} 25 \mathrm{~b}$ in the bull sperm (such as $\mathrm{P} 34 \mathrm{H}$ of the human and $\mathrm{P} 26 \mathrm{~h}$ of the hamster) have been identified, absence of which has been associated with infertility [7] thus they are considered as fertility markers. Similarly, Lessard et al. [7] demonstrated a significant decrease in P25b level after cryopreservation with different magnitude of effect in either egg yolk or milk-based bull semen extender. 
Protection of $\mathrm{P} 25 \mathrm{~b}$ is therefore essential as part of the explanation for reduced bull sperm fertility after cryopreservation. In recent times, the use of antioxidant such as butylated hydroxytoluene (BHT) as a supplement in semen extenders has been shown to improve semen quality parameters such as motility and viability, which is thought to have resulted from its control of oxidants such as ROS. BHT acts as an antioxidant preservative, antiviral, and antimicrobial agent. BHT is an organic soluble molecule, used to stop the auto-oxidation of lipid bilayer and membrane of sperm cells [8]. BHT also scavenges ROS from the surroundings of the spermatozoa and converts these molecules into hydroperoxides [9], thereby reducing the harmful effects of ROS' on sperm cells during storage. Its use efficiently inhibits lipid peroxidation reactions in biological membranes. The BHT supplementation of semen extender has improved sperm quality and reduced lipid peroxidation in different species [10]. In this light, some bull sperm parameters and damage to DNA and acrosome were protected by BHT antioxidant treatments in both chilled and frozen-thawed bull sperm Khumran et al. [11] and Mostafa et al. [12].

The aim of the present study was to investigate the effects of different concentration of BHT on sperm membrane surface protein $\mathrm{P} 25 \mathrm{~b}$ from cryopreserved bull semen in either lecithin $\left(\right.$ Bioxcell $\left.^{\circledR}[\mathrm{BX}]\right)$ or two egg yolk (tris-egg yolk [TEY] and citrate-egg yolk [CEY]) based extenders. The present study was designed to test the hypothesis whether appropriate levels of BHT concentration supplementation will exert a positive protective effect on surface protein P25b of post-thawed bull semen.

\section{Materials and Methods}

\section{Ethical approval}

The study was conducted in accordance with the guideline of the Institutional Animal Care and Use Committee (IACUC) of Universiti Putra Malaysia, with AUP No: R073/2015.

\section{Study design, study period, animals, and management}

The study was conducted between 2015 and 2016 at the Theriogenology and Cytogenetics Unit, Department of Veterinary Clinical Studies, Faculty of Veterinary Medicine, Universiti Putra Malaysia, Serdang, Selangor. Semen samples were collected from bulls at the Taman Pertanian Universiti farm. Protein was extracted, demonstrated, and estimated from bulls' semen samples extended with either of three semen extenders at varying concentrations of BHT, which was kept for 14 days. Three crossbred bulls; Simmental $\times$ Brangus, Brangus $\times$ Hereford, and Kedah-Kelantan $\times$ Brangus were used for semen collection. The bulls were apparently healthy, sexually mature, and fertile. The average age and body weight of the bulls were $5.3 \pm 0.3$ years old and $649.3 \pm 9.7 \mathrm{~kg}$, respectively. They were maintained under uniform management conditions, fed with freshly harvested Surinam grass (Brachiaria decumbens), supplemented with concentrate, palm kernel cake, and provided with mineral licks and water ad libitum.

\section{BHT dose determination}

The BHT used this study was purchased from Sigma-Aldrich - catalog\# B1378-500G (molarity $=220)$. One hundred $\mathrm{mM} / \mathrm{mL}$ stock solution was obtained by dissolving $220 \mathrm{~g}$ of the BHT white crystals in 1 L of absolute ethanol (99\%). The stock was then used subsequently to obtain the desired concentration for every treatment. For example, $10 \mu \mathrm{L}$ of the stock already contains $1 \mathrm{mM}$ of BHT was dissolved in $2 \mathrm{~mL}$ of a diluted semen sample to obtain $0.5 \mathrm{mM} / \mathrm{mL}$ of BHT concentration. However, the stock solution and diluted sample had not been directly mixed together because the ethanol-containing in the stock solution was detrimental to spermatozoa. Therefore, a measure of the stock had always been put into a clean empty test tube first, warmed, and allowed the ethanol to evaporate leaving the dried $\mathrm{BHT}$ crystals to attach to the tube before an appropriate amount of diluted semen sample was added to the test tube which was adequate to make up the desired concentration.

\section{Samples preparation}

Fresh semen samples that had more than $80 \%$ morphologically normal sperm, more than $70 \%$ general motility and a concentration of more than $500 \times 10^{6} \mathrm{sperm} / \mathrm{mL}$ were extended with either BX, TEY, or CEY extenders supplemented with BHT concentrations of 0 (control), $0.5,1.0,1.5,2.0$, and $3.0 \mathrm{mM} / \mathrm{mL}$. The extended samples were left in a water bath at $37^{\circ} \mathrm{C}$ for 5 min to allow uptake of BHT by spermatozoa. Next, the samples were frozen, according to Khumran et al. [11] in liquid nitrogen and stored for 14 days.

\section{Protein extraction and estimation}

The frozen semen samples containing various BHT concentrations and control were thawed in a water bath at $37^{\circ} \mathrm{C}$ for $30 \mathrm{~s}$. Four straws of thawed semen were randomly pooled together from each treatment group and control in separate test tubes. Live and motile spermatozoa were then separated from the dead by the swim-up procedure. Following swim-up separation through sperm-TALP medium, the dead spermatozoa were decanted, and the live ones were further used to extract proteins according to the procedure described by Lessard et al. [7]. First, the spermatozoa were washed 2 times with Dulbecco's phosphate-buffered saline (D-PBS), lysed in lysis buffer $(0.2 \%$ Triton $\times 100$ in D-PBS), pelleted, and finally, proteins were precipitated overnight in ice-cold acetone and then re-suspended in sample buffer. Extracted proteins in sample buffer were treated with protease inhibitor (mix) at 10 $\mu \mathrm{L} / \mathrm{mL}$ to protect proteins from denaturation and kept at $-20^{\circ} \mathrm{C}$ until use. All samples were prepared in duplicates: One member was used for estimation of total protein and the other for sodium dodecyl sulfate-polyacrylamide gel electrophoresis (SDS-PAGE) and subsequently either densitometry or Western blotting (WB) procedures to determine protein $\mathrm{P} 25 \mathrm{~b}$. 
The amount of proteins in each sample per microliter was estimated by a modified Bradford procedure described by Sarsaifi et al. [13]. One mL Bradford reagent was mixed with $100 \mu \mathrm{L}$ samples and bovine serum albumin standards $(0,20,40,60,80$, and $100 \%)$. The reaction absorption was read in a spectrophotometric ELISA reader, equipped with Magellan (7.1 sp1) software (Sunrise. TECAN, Australia). The mixture was loaded into a 96 micro well-plate, first incubated for $5 \mathrm{~min}$ at room temperature $\left(26^{\circ} \mathrm{C}\right)$ then the absorbance was read automatically by the machine at $750 \mathrm{MHz}$ (wavelength). Results obtained from the samples were compared with the standard curve equation. "Y" was determined as the amount of proteins per microliter of a given sample, which was used to load an equal amount of protein onto the gel during SDS-PAGE.

\section{WB}

\section{Sample preparation for $W B$}

The frozen protein samples and protein ladder (PL) (GeneDirex ${ }^{\circledR}$, BLUeye Prestained Ladder) were thawed at room temperature $\left(26^{\circ} \mathrm{C}\right)$. Each sample was mixed with sample loading buffer at 1:1 ratio, heated at $95^{\circ} \mathrm{C}$ for $5 \mathrm{~min}$ before loading into the gel well. Five $\mu \mathrm{L}$ of the ladder were loaded into the first well, followed by $30 \mu \mathrm{g}$ of protein samples (in loading buffer) in the subsequent second to seventh wells and negative control ( $30 \mu \mathrm{L}$ of distilled water) in the eighth well.

\section{$S D S-P A G E$}

A $12 \%$ resolving and $4 \%$ stacking gels were prepared, according to Tam et al. [14]. First, resolving gel was loaded until the green mark of the electrophoresis gasket apparatus, then stacking gel was used to top up the glass gel cast holder. The casted gel was allowed to stand for $2 \mathrm{~h}$ for polymerization and became solid. The polymerized gel was then mounted and ran in a Bio-Rad's (Mini-PROTEAN ${ }^{\circledR}$ Tetra Vertical Electrophoresis) Cell at 80 volt for $2 \mathrm{~h}$ to separate the proteins based on their molecular weights (MW). Two replicates of gel were prepared: One stained with Coomassie blue staining and the other for immune-blotting, detection, and subsequent P25b expression.

\section{Coomassie blue staining and protein P25b densitometry}

Coomassie brilliant blue (CBB) stain was prepared $(0.1 \%[\mathrm{w} / \mathrm{v}]$ CBB R-250, 40\% [v/v] methanol, $10 \%[\mathrm{v} / \mathrm{v}]$ acetic acid) in double-distilled water $\left(\mathrm{ddH}_{2} \mathrm{O}\right) \mathrm{v} / \mathrm{v}$ solution [14]. One of the pair of SDS gels was stained for $30 \mathrm{~min}$ at room temperature $\left(26^{\circ} \mathrm{C}\right)$ with agitation, then destained with a destaining solution $10 \%(\mathrm{v} / \mathrm{v})$ methanol, $10 \%(\mathrm{v} / \mathrm{v})$ acetic acid) 2 times each time for $15 \mathrm{~min}$ and the gel was kept overnight the third time in the destaining solution. The separated proteins appeared as blue bands on the gel (Figure-1), according to their MW against

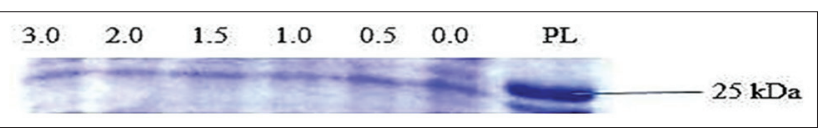

Figure-1: A Coomassie brilliant blue-stained sodium dodecyl sulfate-polyacrylamide gel electrophoresis gel showing bands. $\mathrm{PL}=$ Protein Ladder, $0.0=$ Control. Butylated hydroxytoluene concentrations $(0.5-3.0 \mathrm{mM} / \mathrm{mL})$ treatment wells.

the PL. Protein P25b had $25 \mathrm{kDa}$ and located at the ladder-green band level.

Protein quantification and analysis were conducted directly from the stained gels in the laboratory. Forty-five CBB-stained SDS-PAGE gels, 15 each from either BX, TEY, or CEY extender, were evaluated by densitometry for quantities of P25b. Image J software version IJ 1.46r (a free downloadable image processing software developed at the National Institutes of Health and the Laboratory for Optical and Computational Instrumentation (LOCI), University of Wisconsin). Available at https://imagej.nih.gov/ij/ download.html) was used for protein quantification, according to Miller [15]. A scanned gel image was uploaded onto the software; the colored scan was converted to grey at 32 bits and contrast adjusted. Protein bands were then mapped out in rectangular boxes and the selected area-lane-plotted. The plotted lane appears as vertical peaks indicating the intensity of the selected band. The straight line tool was then selected to mark the width of the base of the peaks made by the intensity of the bands. The peak area was selected by the wand tool and later labeled as percentages using the "label peak" option.

\section{Protein Immunotransfer and immunoblot}

Separated proteins on the second pair of the SDSPAGE-gel were immuno-transferred to nitrocellulose membrane (BioRad, Hercules, California USA). The protein immuno-transfer was accomplished in a sandwich consisting of the gel, nitrocellulose, and blotter paper (BF3, 145×215 mM. Santa Cruz, USA). The sandwich was first soaked in transfer buffer for $20 \mathrm{~min}$ before running. Semi dry transfer cell (SD Tans-Blot, Bio-Rad) was used at 25 volts for $2 \mathrm{~h}$.

The nitrocellulose carrying the transferred protein was washed in $\mathrm{dH}_{2} \mathrm{O} 3$ times, then incubated in Ponceau-S (PS) stain for 20 min to confirm the transfer before proceeding to WB. The red protein bands (Figure-2) on the membrane after the PS-stain indicate quantities of proteins that have been transferred. The gel from which the protein has been transferred was also stained with CBB stain, this would further confirm if the transfer was complete in which case, there would be a plain gel after destaining (without bands) or a partial transfer in which case there would still be remaining bands on the gel after destaining.

The membrane was first stained with PS-stain in order to detect protein bands and ensure complete transfer from the gel, then washed thoroughly with $\mathrm{ddH}_{2} \mathrm{O}$, then incubated for $1 \mathrm{~h}$ at room temperature 


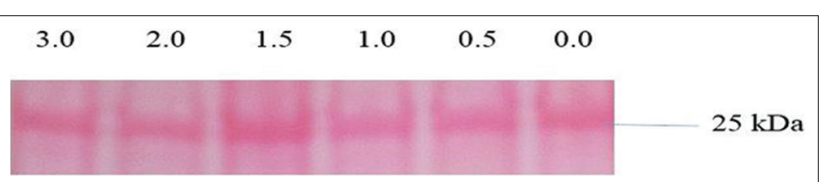

Figure-2: Ponceau-S stained nitrocellulose membrane showing transferred protein bands. $0.0=$ Control. Butylated hydroxytoluene concentrations $(0.5-3.0 \mathrm{mM} / \mathrm{mL})$ treatment wells.

in a blocking buffer. Following blocking, the nitrocellulose was washed 3 times, 5 min each in Tris-Buffer Saline and Tween 20 (TBS-T) and thereafter, incubated in primary antibody $\left(1^{\circ}-\mathrm{Ab}\right)$, Rabbit-polyclonal RAB3B (NBP2-20045, NOVUS BIOLOGICALS) overnight at $4{ }^{\circ} \mathrm{C}$ at $1: 1000$ dilution with $\mathrm{Ab}$-dilution solution ( $5 \%$ fat-free skimmed milk in TBS). The $1^{\circ}-\mathrm{Ab}$ was decanted the following day and the blot was washed in TBS-T as before, then incubated for $1 \mathrm{~h}$ at room temperature in secondary antibody $\left(2^{\circ}-\mathrm{Ab}\right)$, Goat anti-rabbit immunoglobulin G (IgG) antibody horseradish peroxidase conjugate (NB730-H, NOVUS BIOLOGICALS) at 1:30,000 dilution. The washing solution was again used to wash the blotted nitrocellulose 3 times as before and the enzyme, TMB membrane peroxidase substrate (KPl) was used to incubate the blotted membrane for $15 \mathrm{~min}$. Rabbit polyclonal anti-beta-actin antibody (ab8227, Abcam $\left.^{\circledR}\right)$, known to detect beta-actin proteins at $40 \mathrm{kDa} \mathrm{MW}$, was used as a positive control. These antibody reactions were stable in all three extender groups.

\section{Statistical analysis}

Statistical analysis system (SAS V 9.1, SAS Inst. Inc. Cary, North Carolina) was used for analysis. Data were checked for normality using the univariate procedure and the results are presented as means \pm standard errors of the mean. The relative density (RD) of the protein bands area of each treatment in relation to the control for each extender (BX, TEY, and CEY) was analyzed by one-way ANOVA. Duncan's multiple range test was used as post hoc against control. $\mathrm{p}<0.05$ was considered significant.

\section{Results}

\section{Protein P25b expression by WB}

Antigen-antibody complexes were expressed as dark blue stains on the blotted membrane. P25b protein precipitated at $25 \mathrm{kDa} \mathrm{MW}$ level as indicated by the BLUeye ${ }^{\circledR}$ PL when used in Tris-glycine- $20 \%$ buffer. The dark blue stains protein bands were visible as confirmation of the bands on the corresponding Coomassie blue-stained gel (Figure-3).

\section{Protein densitometry}

The areas marked by the intensity of the protein bands were measured and resultant $\mathrm{RD}$ of the treatments compared to the control for BX extender is shown in Figure-4. The protein was significantly preserved at BHT concentration of $0.5 \mathrm{mM} / \mathrm{mL}$ than in the control and treatments at BHT concentrations of $1.0,1.5,2.0$, and $3.0 \mathrm{mM} / \mathrm{mL}$. The protein was

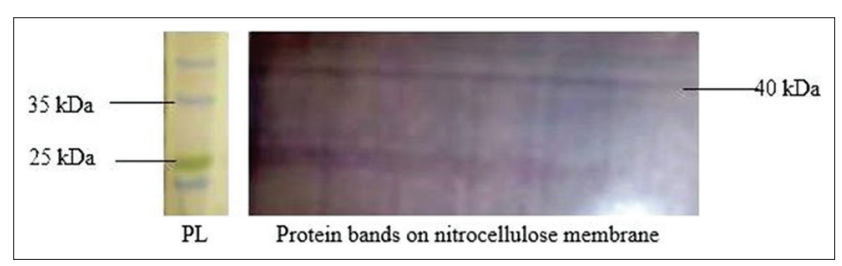

Figure-3: A Western blot showing very faint protein bands, beta-actin reacted at 40 and $\mathrm{P} 25 \mathrm{~b}$ at $25 \mathrm{kDa}$.

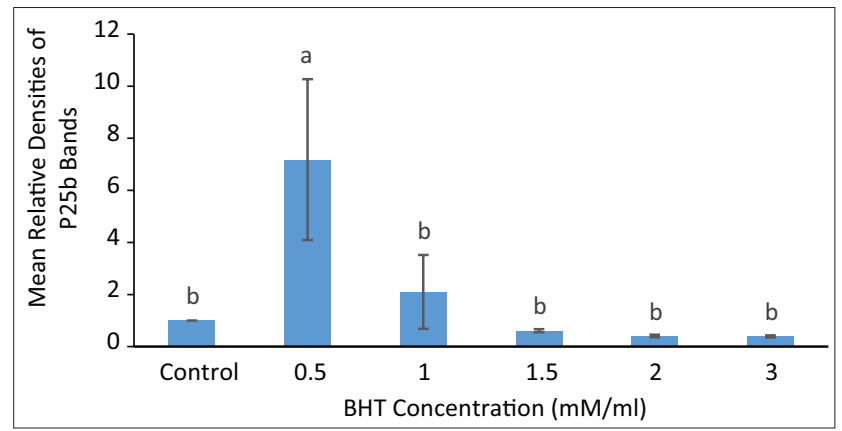

Figure-4: Relative densities of protein bands in treatments compared in Bioxcell ${ }^{\circledR}$ extender. Data are expressed as means \pm standard error, $n=15$. Different letters $a, b$ denote differences $(p<0.05)$ between treatments.

most severely damaged at the BHT concentration of $3.0 \mathrm{mM} / \mathrm{mL}$.

Figure- 5 shows the RD of the protein bands in the treatments compared to the control for TEY extender. The intensity of the protein bands was the same in control and treatment concentrations of $0.5,1.5,2.0$, and $3.0 \mathrm{BHT} \mathrm{mM} / \mathrm{mL}$, in which the protein P25b was significantly lower than in the treatment concentration of 1.0 BHT $\mathrm{mM} / \mathrm{mL}$.

In Figure-6, the protein P25b was significantly better in BHT concentration of $1.0 \mathrm{mM} / \mathrm{mL}$ group than in control, 2.0 and $3.0 \mathrm{mM} / \mathrm{mL}$ BHT concentration then followed by $1.5 \mathrm{mM}$ BHT which appeared to be the same with the control, $1.5,2.0$, and $3.0 \mathrm{mM} / \mathrm{mL}$.

\section{Discussion}

The effects of various BHT treatments and controls on bull fertility marker protein $\mathrm{P} 25 \mathrm{~b}$ were elucidated in this study. The quantification of the protein in question was conducted by direct densitometry from CBB-stained SDS-PAGE gel. To ensure that we were dealing with the target protein of interest, the band corresponding to $25 \mathrm{kDa} \mathrm{MW}$ was identified, and its specific reactions with primary (Rabbit-polyclonal RAB3B) and secondary antibody (Goat anti-rabbit $\mathrm{IgG}$ ) complexes were detected by WB. The WB result detected the P25b at $25 \mathrm{kDa}$. This is in tandem with the MW position at which Lessard et al. [7] detected the same protein by WB [5]. Detected P25b at $28 \mathrm{kDa}$, but this is not uncommon that protein peptides showed up slightly higher or lower than its theoretical MW position. Although, one particular reason has not been agreed on, many factors (such as incomplete unfolding and modification due to others) are thought to influence the mobility of proteins on gel, thus 


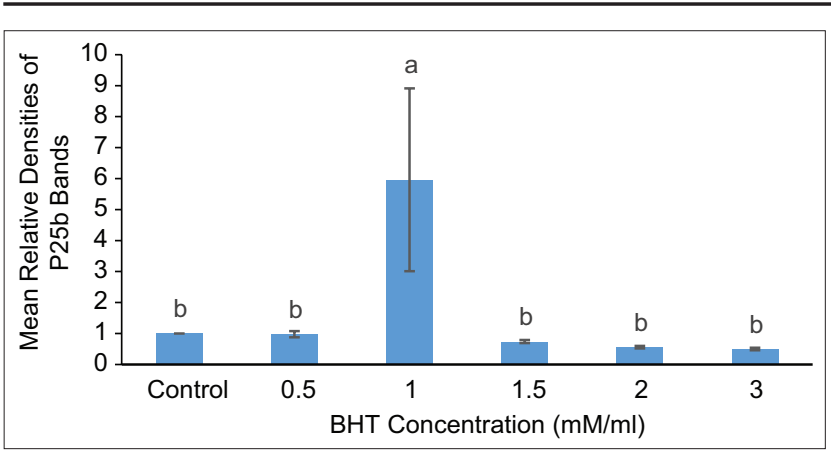

Figure-5: Relative densities of protein bands in treatments compared in tris-egg yolk extender. Data are expressed as means \pm standard error, $n=15$. Different letters $a, b$ denote differences $(p<0.05)$ between treatments.

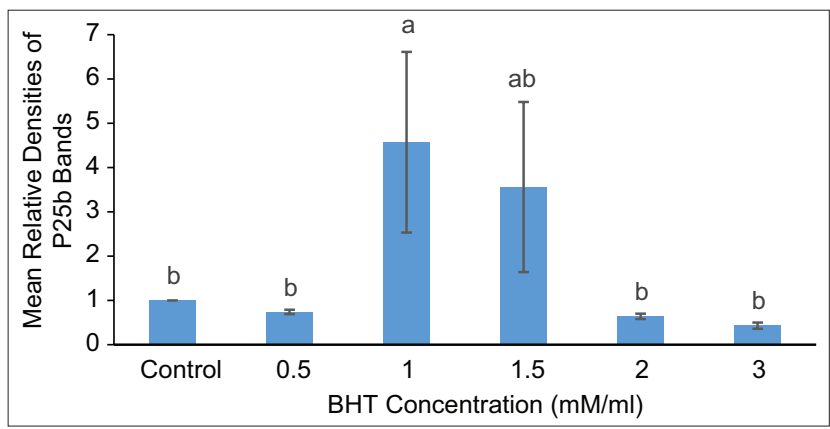

Figure-6: Relative densities of protein bands in treatments compared in citrate-egg yolk extender. Data are expressed as means \pm standard error, $n=15$. Different letters $a, b$ denote differences $(p<0.05)$ between treatments.

making the proteins appear slightly bigger or lesser than expected [16].

SDS-PAGE gel densitometry revealed that P25b was protected in optimum treated bull sperm samples than in control, precisely at BHT concentration of $0.5 \mathrm{mM} / \mathrm{mL}$ in BX, $1.0 \mathrm{mM} / \mathrm{mL}$ in TEY, and 1.0 to $1.5 \mathrm{mM} / \mathrm{mL}$ in CEY. By implication, the use of antioxidant BHT at appropriate concentrations in different extenders improved the protection to the bull fertility marker protein during cryopreservation. The BHT concentration that gave optimum protection in this study was similar to report by Mostafa et al. [12] using BHT to preserve buffalo semen. This is understood to influence the fertility potential of frozen-thawed bull spermatozoa, since this protein partakes in the process of fertilization and that its low abundance or absence was partly responsible for infertility of some bulls [17]. It has also been reported that the protein P25b concentration depleted significantly after cryopreservation resulting in diminished fertility [7]. The findings in the current study are in agreement with Karunakaran and Devanathan [18] in which they reported the abundance of fertility-related proteins such as $\mathrm{P} 25 \mathrm{~b}$ in fertile bulls and the proteins' absence in the infertile bull. This implies that if fertility is reduced due to either low levels or damage of P25b by cryopreservation, the fertility could be saved by protecting such protein. The outcome in this study further reiterates the superiority of BHT's treatment at those optimum concentrations for the different extenders. In recent studies, Khumran et al. [11] demonstrated that BHT had improved the quality parameters (general motility, progressive motility, morphology, acrosome integrity, DNA integrity, and malondialdehyde of sperm) of the bull semen when added at the same concentrations of 0.5 in BX and 1.0 to $1.5 \mathrm{mM} / \mathrm{mL}$ in TEY and CEY as it is the case in the present study. However, it is also observed that, unlike in the previous studies where some bull sperm [19], buffalo sperm [12] quality parameter characteristics deteriorated significantly against the control in higher BHT treatment groups. Here, the RD of protein in BHT treatment groups (other than the optimum groups of 0.5 in BX, 1.0 in TEY and CEY) remained the same with the control in all extenders. This may mean that, though the control might be better than other treatment in certain parameters, such was not adequate to produce the difference in abundance of the fertility marker protein between them.

Although the WB result detected the protein antibody reactions, this only confirmed the identity of protein that we were dealing with. However, the observed bands were very faint even in the samples with the optimum treatment in all the extenders. The same was reported in the previous studies where P25b was expressed. The protein $\mathrm{P} 25 \mathrm{~b}$ protein bands were more robust on SDS-PAGE gel than on membranes after WB in this study and also in Lessard et al. [7] and Parent et al. [17]. This is believed to happen because the processes involved in WB usually expose the protein to various factors that could lead to either partial loss of protein or dark membrane backgrounds that may camouflage with the bands, making them barely visible $[20,21]$.

\section{Conclusion}

Bull sperm surface protein $\mathrm{P} 25 \mathrm{~b}$ was protected during cryopreservation when BHT was used at 0.5 $\mathrm{mM} / \mathrm{mL}$ in BX and $1.0 \mathrm{mM} / \mathrm{mL}$ in TEY and CEY extenders. However, the damage to this protein was not significant between the control and treatment regimens of $1.0,1.5,2.0$, and $3.0 \mathrm{mM} / \mathrm{mL}$ BHT in BX and $0.5,2.0$, and $3.0 \mathrm{mM} / \mathrm{mL}$ in TEY and CEY extenders.

\section{Authors' Contributions}

AMK, NY, YR, MOA, and HW: participated in the study conception and design. AMK, HH, and KA: acquisition of data. AMK: analyzed and interpreted the data. AMK, and TKB: drafted the manuscript. All authors critically revised the manuscript for important intellectual content and approved the final manuscript.

\section{Acknowledgments}

This research was supported by Universiti Putra Malaysia (UPM) Research Grant Scheme (9324200).

\section{Competing Interests}

The authors declare that they have no competing interests. 


\section{Publisher's Note}

Veterinary World remains neutral with regard to jurisdictional claims in published map and institutional affiliation.

\section{References}

1. Masoudi, R., Shahneh, A.Z., Towhidi, A., Kohram, H., Sharif, A.A. and Sharafi, M. (2017) Fertility response evaluation of artificial insemination methods in sheep with fresh and frozen-thawed semen. Cryobiology, 73(2017): 77-80.

2. Solihati, N., Rasad, S.D., Setiawan, R., Foziah, E.N. and Wigiyanti, E.T. (2018) Semen quality of post thawed local rams in tris egg yolk extender with different glutathione level. IOP Conf. Ser. Earth Environ. Sci., 119(1): 1-9.

3. Nitin, R., Sanjay, C., Grewal, N. and Nishant, K. (2018) A review on semen extenders and additives used in cattle and buffalo bull semen preservation. J. Entomol. Zool. Stud., 6(3): 239-245.

4. Frenette, G., Lessard, C. and Sullivan, R. (2002) Selected proteins of "prostasome-like particles" from epididymal cauda fluid are transferred to epididymal caput spermatozoa in bull. Biol. Reprod., 67(1): 308-313.

5. Girouard, J., Frenette, G. and Sullivan, R. (2009) Seminal plasma proteins regulate the association of lipids and proteins within detergent-resistant membrane domains of bovine spermatozoa. Biol. Reprod., 78(5): 921-931.

6. Iida, H., Yoshinaga, Y., Tanaka, S., Toshimori, K. and Mori, T. (1999) Identification of Rab3A GTPase as an acrosome-associated small GTP-binding protein in rat sperm. Dev. Biol., 211(1): 144-155.

7. Lessard, C., Parent, S., Leclerc, P., Bailey, J.L. and Sullivan, R. (2000) Cryopreservation alters the levels of the bull sperm surface protein P25b. J. Androl., 21(5): 700-707.

8. Thangamani1, A., Srinivas, M., Prasad, B.C., Anusha, K. and Rao, K.S. (2018) Semen additives to improve motility and fertility of bovine spermatozoa-a review. Int. J. Environ. Sci. Technol., 7(2): 554-560.

9. Merino, O., Aguagui na, W.E., Esponda, P., Risopatron, J., Isachenko, E., Isachenko, V. and Sanchez, R. (2015) Protective effect of butylated hydroxytoluene on sperm function in human spermatozoa cryopreserved by vitrification technique. Andrologia, 47(2): 186-193.

10. Alcay, S., Gokce, E., Toker, M.B., Onder, N.T., Ustuner,B., Uzabac, E., Gul, Z. and Cavus, S. (2016) Freeze-dried egg yolk based extenders containing various antioxidants improve post-thawing quality and incubation resilience of goat spermatozoa. Cryobiology, 72(3): 269-273.

11. Khumran, A.M., Yimer, N., Rosnina, Y., Ariff, M.O., Wahid, H., Kaka, A., Ebrahimi, M. and Sarsaifi, K. (2015) Butylated hydroxytoluene can reduce oxidative stress and improve quality of frozen-thawed bull semen processed in lecithin and egg yolk based extenders. Anim. Reprod. Sc., 163(2015): 128-134.

12. Mostafa, A.A., El-Belely, M.S., Ismail, S.T., El-Sheshtawy, R.I. and Shahba, M.I. (2019) Effect of butylated hydroxytoluene on quality of pre-frozen and frozen buffalo semen. APJR, 8(1): 20-24.

13. Sarsaifi, K., Haron, A.W., Vejayan, J., Yusoff, R., Hani, H., Omar, M.A., Hong, L.W., Yimer, N., Ju, T.Y. and Othman, A.M. (2015) Two-dimensional polyacrylamide gel electrophoresis of Bali bull (Bos javanicus) seminal plasma proteins and their relationship with semen quality. Theriogenology, 84(6): 956-968.

14. Tam, Y.J., Zeenathul, N.A., Rezaei, M.A., Azmi, M.L.M., Bahaman A.R., Lo, S.C., Tan J.S. and Hani, H. (2016) Twostep purification strategy for enhanced recovery of recombinant hepatitis B surface antigen from Pichia pastoris. Sep. Sci. Technol., 51(5): 816-829.

15. Miller, L. (2010) Analyzing Gels and Western Blots with ImageJ. Miscellaneous Topics Vaguely Related to Science. Available from: http://www.Lukemiller.org. Retrieved on 18/06/2016.

16. Rath, A., Glibowicka, M., Nadeau, V.G, Chen, G. and Deber, C.M. (2009) Detergent binding explains anomalous SDS-PAGE migration of membrane proteins. Proc. Natl. Acad. Sci., 106(6): 1760-1765.

17. Parent, S., Lefièvre, L., Brindle, Y. and Sullivan, R. (1999) Bull subfertility is associated with low levels of a sperm membrane antigen. Mol. Reprod. Dev., 52(1): 57-65.

18. Karunakaran, M. and Devanathan, T.G. (2017) Evaluation of bull semen for fertility-associated protein, in vitro characters and fertility. J. Appl. Anim. Res., 45(1): 136-144.

19. Ijaz, A., Hussain, A., Aleem, M., Yousaf, M.S. and Rehman, H. (2009) Butylated hydroxytoluene inclusion in semen extender improves the post-thawed semen quality of Nili-Ravi buffalo (Bubalus bubalis). Theriogenology, 71(8): 1326-1329.

20. Aebersold, R., Burlingame, A.L. and Bradshaw, R.A. (2013) Western blots versus selected reaction monitoring assays: Time to turn the tables? MCP, 12(9): 2381-2382.

21. Gassmann, M., Grenacher, B., Rohde, B. and Vogel, J. (2009) Quantifying Western blots: Pitfalls of densitometry. Electrophoresis, 30(11): 1845-1855. 